\title{
Caprazamycins: Promising lead structures acting on a novel antibacterial target MraY
}

\author{
Bhautikkumar Patel, ${ }^{\mathrm{a}, \mathrm{b}}$ Philip Ryan, ${ }^{\mathrm{a}, \mathrm{b}}$ Vivek Makwana, ${ }^{\mathrm{a}, \mathrm{b}}$ Matthew Zunk, ${ }^{\mathrm{a}, \mathrm{b}, \mathrm{c}}$ Santosh \\ Rudrawar, ${ }^{\mathrm{a}, \mathrm{b}, \mathrm{c} \dagger}$ Gary Grant ${ }^{\mathrm{a}, \mathrm{b} \dagger}$
}

${ }^{a}$ School of Pharmacy and Pharmacology, Griffith University, Gold Coast, QLD 4222, Australia ${ }^{b}$ Quality Use of Medicines Network, Gold Coast, QLD 4222, Australia

${ }^{c}$ Menzies Health Institute Queensland, Griffith University, Gold Coast, QLD 4222, Australia

Corresponding authors:

1) Dr Santosh Rudrawar

E-mail address: $\underline{\text { s.rudrawar@griffith.edu.au }}$

2) Dr Gary Grant

E-mail address: g.grant@griffith.edu.au 
Abstract: The present status of antibiotic resistant requires an urgent invention of novel agents that act on clinically unexplored antibacterial targets. The enzyme MraY (phospho-MurNAcpentapeptide translocase), essential for bacterial cell wall synthesis, fulfils this criterion as it has not been explored as a target in a clinical context. Specifically, the enzyme is involved in the lipidlinked cycle of peptidoglycan biosynthesis and is reportedly targeted by naturally-occurring nucleoside antibiotics. The antimicrobial 'caprazamycin' class of nucleoside antibiotics targets Mycobacterium tuberculosis and clinically relevant Gram-negative bacteria such as Pseudomonas aeruginosa besides various drug resistant strains and is therefore an eligible starting point for the development of novel agents. In this review, we aim to summarise the structure-activity relationships of the natural, semi-synthetic as well as synthetic analogues of nucleoside antibiotic caprazamycins. This review highlights caprazamycins as promising lead structures for development of potent and selective antimicrobial agents that target MraY, the bacterial enzyme involved in the first membrane-dependent step in bacterial peptidoglycan assembly.

Keywords: Antibacterial; antibiotics; MraY; nucleoside natural product; uridylpeptide; caprazamycins. 


\section{Introduction}

Accelerating antibiotic resistance has become a global public-health problem [1-2]. Multidrug resistance is rising to dangerously high levels in all parts of the world, threatening our ability to treat common infections, especially multidrug-resistant Gram-negative bacteria (MDR GNB). Consequently, there is an urgent need for new classes of antibiotics with clinically unexploited modes of action [3]. Bacterial cell-wall peptidoglycan layer biosynthesis is a well-recognised antibacterial target for clinically useful $\beta$-lactam (penicillin) and glycopeptide (vancomycin) classes of antibiotics [4], however these well-established antibiotics target the later, lipid-linked extracellular steps in peptidoglycan assembly. The recent advance in the availability of peptidoglycan biosynthetic intermediates generated significant interest towards the earlier, membrane-associated core steps of peptidoglycan formation for the development of antibacterial agents [5]. Bacterial cell wall assembly remains an attractive antibacterial target for drug design [6] and so the integral membrane protein involved in the first step of bacterial peptidoglycan assembly

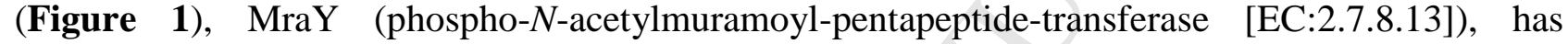
consequently become a novel drug target for antibacterial agents [7].

The naturally-occurring caprazamycin class of nucleoside antibiotics target the MraY enzyme, unlike antibiotics from those of existing peptidoglycan inhibitors (including penicillins and vancomycin) [8, 9]. This new class of antibiotics targeting MraY are active against MDR GNB [910]. Interestingly, candidates from the mureidomycin class of nucleoside antibiotics are active against clinical isolates of $\beta$-lactam and quinolone-resistant strains of $P$. aeruginosa [11]. The caprazamycin-derived antibiotic CPZEN-45, exhibits potent antibacterial activity against several multidrug-resistant strains of Mycobacterium, including extensively multi-drug-resistant TB (XDRTB) [12], qualifying it as a promising antitubercular drug candidate [13]. MraY-targeting caprazamycins are therefore speculated to become promising, novel, antibacterial leads effective against drug-resistant bacterial pathogens. Several review articles have enriched the knowledgebase recently, focussing on isolation, biosynthesis, chemical synthesis, modelling and biological activity of nucleoside antibiotics [7, 10,14-24]. Herein, we highlight the structure and function of naturally occurring caprazamycin and discuss its synthetic derivatives' competencies as broad-spectrum antibacterial agents.

\section{MraY -novel antibacterial target}

The peptidoglycan cell wall layer is found in both Gram-positive and Gram-negative bacteria. Peptidoglycan biosynthesis is a well-established target for antibacterial action [25] and takes place across three biosynthetic stages; Stage I: peptidoglycan precursor synthesis in the cytosol, Stage II: transportation of cytoplasmic precursor across the membrane to the periplasm, and Stage III: 
peptidoglycan cross-linking via transpeptidation [26]. The MraY enzyme is a member of the polyprenyl-phosphate $N$-acetyl hexosamine 1-phosphate transferase (PNPT) superfamily [27-28]. The enzymes' role in bacterial peptidoglycan assembly is to transfer the UDP- $N$-acetylmuramoyl (UDP-MurNAc) pentapeptide (-L-Ala 1 -D- $\gamma$-Glu -Lys/DAP $_{3}$-D-Ala 4 -D-Ala 5 -COOH) (Park's nucleotide) to the membrane-soluble $\mathrm{C}_{55}$ isoprenoid carrier lipid known as bactoprenol-phosphate (bactoprenol-P), resulting in the formation of lipid I (undecaprenyl-pyrophosphoryl-MurNAcpentapeptide) [27]. The MurNAc-pentapeptide is subsequently glycosylated with an $N$ acetylglucosamine (GlcNAc) residue forming lipid II, which is then flipped to the outer surface of the cytoplasmic membrane before being further elongated via cross-linking (Figure 1). The catalytic activity of MraY is an essential prerequisite for the transfer of peptidoglycan synthesis building blocks to the outer surface of the membrane. As such, MraY is often labelled a translocase. Gene knockout experiments in Escherichia coli and Streptococcus pneumoniae identified the involvement of MraY in the second stage of bacterial cell wall biosynthesis as an essential process for bacterial cell viability and growth [29-30]. Given the critical role of the peptidoglycan layer in the survival of bacteria, potent disruption of its formation via inhibition of essential enzymes like MraY offers a novel antibacterial strategy [31]. Furthermore, as MraY enzyme is not present in eukaryotes, selective inhibitors should be free from mechanism-based toxicity, qualifying it as a promising target for development of next generation antibiotics [7].

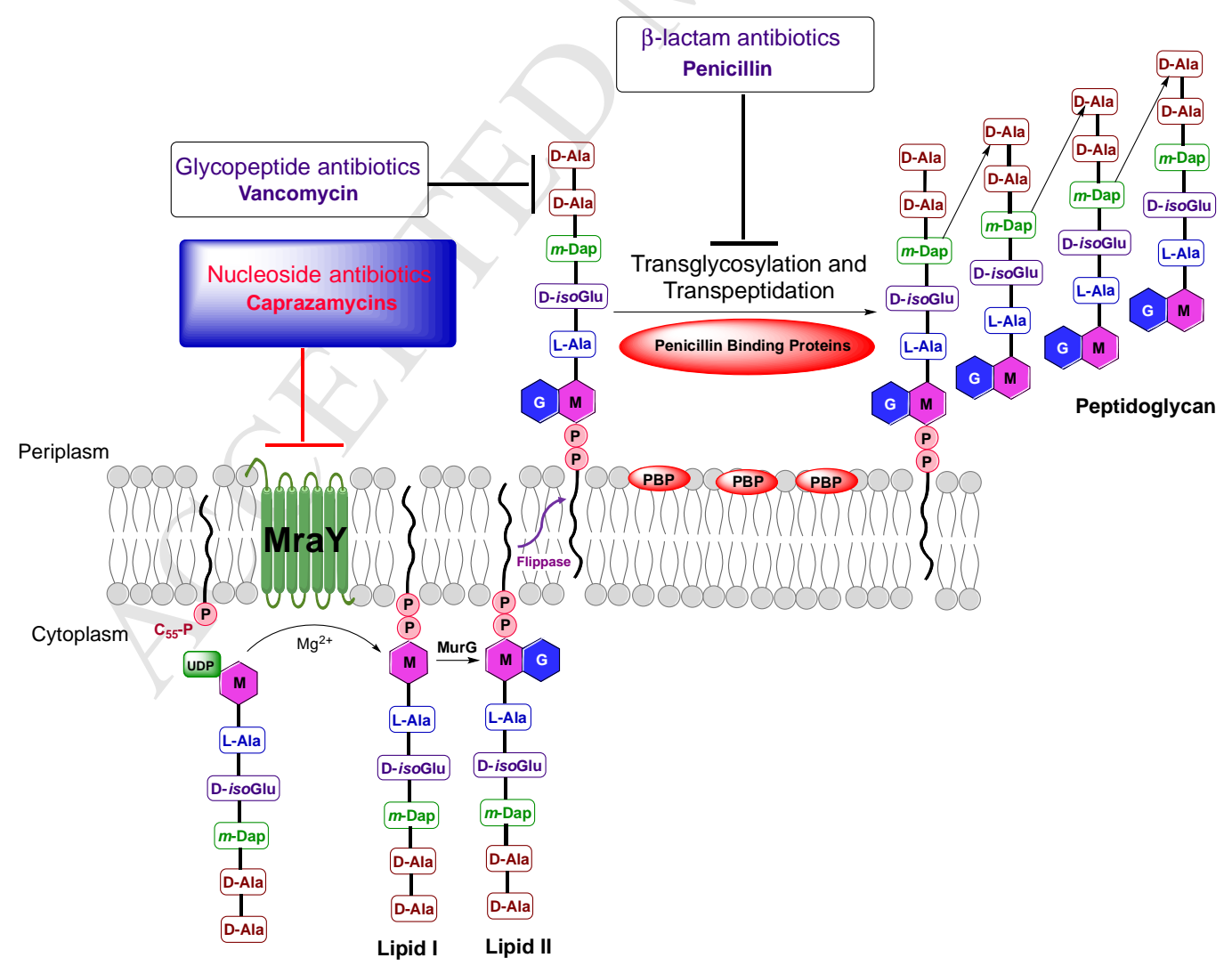

Figure 1. Peptidoglycan biosynthesis pathway, showing the site of action of the natural product nucleoside antibiotic- 


\section{Natural product nucleoside antibiotics - MraY inhibitors}

MraY is the target of many of nucleoside natural product antibiotics including liposidomycins, caprazamycins, capuramycins, muraymycins and uridylpeptides $[10,14,19]$. It is believed that these natural products compete with UDP-MurNAc-pentapeptide as MraY substrates [32]. Naturally occurring MraY inhibitors exhibit a wide range of biological actions, specifically antibacterial, antifungal, antiviral, insecticidal, immunostimulative, immunosuppressive and antitumor activities [15]. Fortunately, the availability of X-ray crystal structures of MraY-inhibitor complexes [apo (PDB: 5JNQ) (MraY from Aquifex aeolicus), tunicamycin- (PDB: 6BW5) (MraY from Clostridium bolteae), and muraymycin-bound (PDB: 5CKR) (MraY from Aquifex aeolicus)] have provided significant insight into the structural prerequisites for selective inhibition of MraY [27, 33-35]. As such, there now exists an exciting opportunity for structure-based design and these natural products provide a promising starting point for the discovery of next generation antibacterial agents with increased potency $[10,14,19]$.

Antibacterial nucleoside antibiotics can be further divided into four subfamilies based on their chemical structures: $i$ ) ribosamino-uridines; ii) tunicamycins; iii) uridylpeptides and iv) capuramycins (SI Figure 1) [19]. Members of these families are often referred to as uridine-based nucleosides due to their shared structural scaffold. Caprazamycins, like other ribosamino-uridines (i.e. muraymycins and liposidomycins), share an identical aminoglycosylated $5^{\prime}$ - $C$-glycyluridine core, making it a common structural motif within the class $[19,36]$.

Members of the caprazamycin (CPZ, 1) class were first reported in 2003 by Igarashi et al. via the isolation of caprazamycin B (CPZ-B, 2) from the cultured broth of the Streptomyces sp. MK730-62F2 [37]. These compounds have similar structures to liposidomycins though they differ in the 2 "-sulfate group of the aminoribose and bear a permethylated L-rhamnoside $\beta$-glycosidically linked to the 3-methylglutaryl moiety (Figure 3) [21]. Various analogues of naturally occurring caprazamycins A-G (2-8) were isolated from a common source and were characterized in 2005 by Igarashi et al [38]. They were found to have very similar chemical functionalities, yet differed in the length of their lipophilic side chains. The caprazamycin structure can be divided into four structural subunits: uridine (subunit $\boldsymbol{A}$ ), 5"-aminoribose (subunit $\boldsymbol{B}$ ), diazepanone ring (subunit $\boldsymbol{C}$ ) and variable fatty acyl side chain (subunit $\boldsymbol{D}$ ). Caprazol was characterized through X-ray crystallographic study to reveal the presence of the key subunits $\mathbf{A}, \mathbf{B}$ and $\mathbf{C}$ [38]. The caprazamycins 'western zone' consists of an L-rhamnoside attached to the fatty acyl side chain (subunits D) via a $\beta$-methylglutarylether [39] (see Figure 2). 


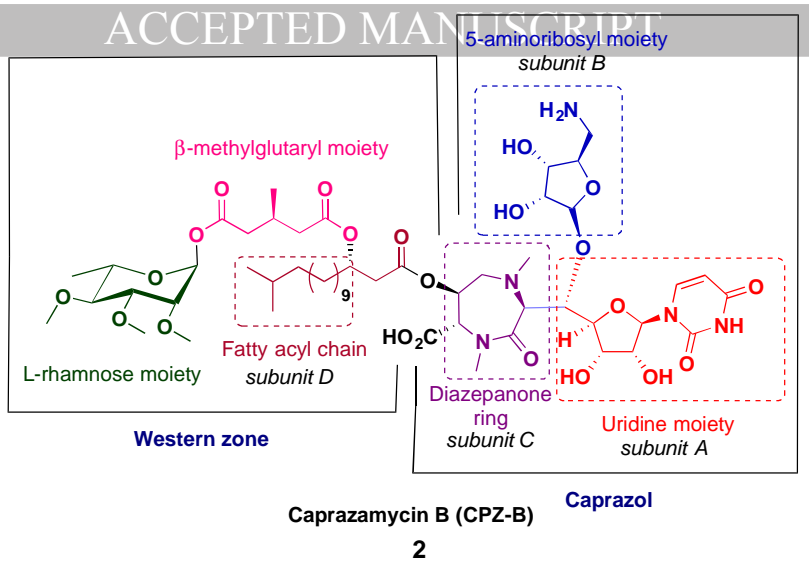

Figure 2: Structural features of caprazamycin

\section{Structure-activity relationships}

In this section, we analyse key pharmacophores within the structures of bioactive caprazamycins and summarise critical structural elements required for translating their potent antibacterial activity across to novel, rationally designed analogues.

\subsection{Natural product caprazamycins $A-G$}

The natural analogues of caprazamycins A-G (2-8) have displayed an excellent anti-mycobacterial profile in vitro against both drug-susceptible and multidrug-resistance Mycobacterium tuberculosis strains without any observation of significant toxicity against mouse models (Table 1) [37, 40].

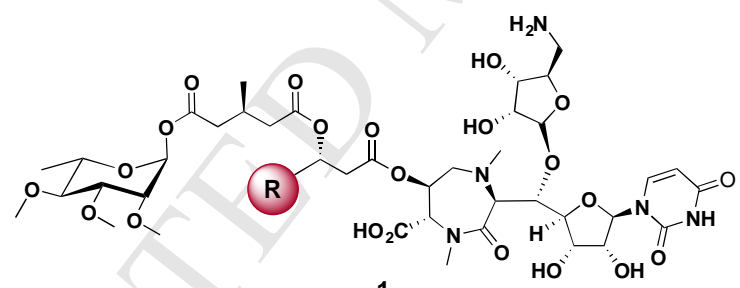

1

Table 1: Chemical structures of naturally occurring caprazamycins and their antimicrobial spectrum

Caprazamycin
3
CPZ-A


M. tuberculosis (MIC $=3.13-12.5 \mu \mathrm{g} / \mathrm{mL}, 1.56 \mu \mathrm{g} / \mathrm{mg})^{[58,63]}$

M. avium $(\mathrm{MIC}=6.25-50 \mu \mathrm{g} / \mathrm{mL},<0.025 \mu \mathrm{g} / \mathrm{mg})^{[58]}$

M. intracellulare $(\mathrm{MIC}=1.56-25 \mu \mathrm{g} / \mathrm{mL},=0.78 \mu \mathrm{g} / \mathrm{mg})^{[58]}$

M. bovis $(\mathrm{MIC}=3.13 \mu \mathrm{g} / \mathrm{mL})^{[58]}$

151

$2 \quad$ CPZ-B

152

153

154

155

156

157

158

159

160

161

162

163

164

165

166

167

168

169

170

171

6 CPZ-E

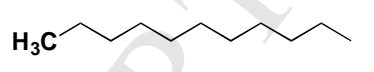

4 CPZ-C

$\mathrm{H}_{3} \mathrm{C}$

5 CPZ-D

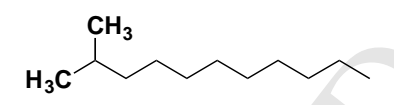

M. phlei $(\mathrm{MIC}=3.13 \mu \mathrm{g} / \mathrm{mL})^{[63]}$

M. vaccae $(\mathrm{MIC}=0.39 \mu \mathrm{g} / \mathrm{mL})^{[63]}$

M. fortuitum (MIC $=50 \mu \mathrm{g} / \mathrm{mL})^{[63]}$

S. aureus $(\mathrm{MIC}=1.56-6.25 \mu \mathrm{g} / \mathrm{mL})^{[63]}$

M. luteus $(\mathrm{MIC}=3.13 \mu \mathrm{g} / \mathrm{mL})^{[63]}$

B. anthracis (MIC $=0.78 \mu \mathrm{g} / \mathrm{mL})^{[63]}$

B. subtilis $(\mathrm{MIC}=6.25-12.5 \mu \mathrm{g} / \mathrm{mL})^{[63]}$

B. cereus $(\mathrm{MIC}=3.13 \mu \mathrm{g} / \mathrm{mL})^{[63]}$

C. bovis $(\mathrm{MIC}=3.13 \mu \mathrm{g} / \mathrm{mL})^{[63]}$

E. coli $(\mathrm{MIC}=100 \mu \mathrm{g} / \mathrm{mL})^{[63]}$

M. smegmatis $(\mathrm{MIC}=0.78-1.56 \mu \mathrm{g} / \mathrm{mL})^{[63]}$

M. phlei $(\mathrm{MIC}=1.56 \mu \mathrm{g} / \mathrm{mL})^{[63]}$

M. vaccae $(\mathrm{MIC}=0.39 \mu \mathrm{g} / \mathrm{mL})^{[63]}$

M. fortuitum $(\mathrm{MIC}=12.5 \mu \mathrm{g} / \mathrm{mL})^{[63]}$

M. tuberculosis (MIC $=0.78 \mu \mathrm{g} / \mathrm{mg})^{[63]}$

M. avium (MIC $<0.025 \mu \mathrm{g} / \mathrm{mg}$ ) ${ }^{[63]}$

M. intracellulare $(\mathrm{MIC}=0.78 \mu \mathrm{g} / \mathrm{mg})^{[63]}$

M. smegmatis (MIC $=0.39-1.56 \mu \mathrm{g} / \mathrm{mL})^{[63]}$

M. phlei $(\mathrm{MIC}=1.56 \mu \mathrm{g} / \mathrm{mL})^{[63]}$

M. vaccae $(\mathrm{MIC}=0.39 \mu \mathrm{g} / \mathrm{mL})^{[63]}$

M. fortuitum $(\mathrm{MIC}=12.5 \mu \mathrm{g} / \mathrm{mL})^{[63]}$

M. tuberculosis $(\mathrm{MIC}=0.78 \mu \mathrm{g} / \mathrm{mg})^{[63]}$

M. avium (MIC $<0.025 \mu \mathrm{g} / \mathrm{mg})^{[63]}$

M. intracellulare $(\mathrm{MIC}=0.78 \mu \mathrm{g} / \mathrm{mg})^{[63]}$

M. smegmatis $(\mathrm{MIC}=0.78-1.56 \mu \mathrm{g} / \mathrm{mL})^{[63]}$

M. phlei $(\mathrm{MIC}=1.56 \mu \mathrm{g} / \mathrm{mL})^{[63]}$

M. vaccae $(\mathrm{MIC}=0.78 \mu \mathrm{g} / \mathrm{mL})^{[63]}$

M. fortuitum $(\mathrm{MIC}=12.5 \mu \mathrm{g} / \mathrm{mL})^{[63]}$

M. tuberculosis $(\mathrm{MIC}=1.56 \mu \mathrm{g} / \mathrm{mg})^{[63]}$

M. $\operatorname{avium}(\mathrm{MIC}=0.1 \mu \mathrm{g} / \mathrm{mg})^{[63]}$

M. intracellulare $(\mathrm{MIC}=1.56 \mu \mathrm{g} / \mathrm{mg})^{[63]}$ 
Despite their potent antibiotic activity, the naturally occurring caprazamycins are not considered eligible drug candidates due to: $i$ ) their sourcing limitations and $i$ ) complex caprazamycin scaffold, which demands challenging multi-step synthesis with numerous poor yielding steps [41-42]. Increasingly, medicinal chemistry is being employed to generate synthetic analogues of lesser structural complexity that retain comparable or even superior function [17]. Evaluation of each subsites' structural requirements facilitates the truncation of the caprazamycin scaffold by removal of the non-essential components to generate novel derivatives with increased potency or druglikeness. Simplified analogues produced via synthetic or semisynthetic protocols are described in the following sections according to the subsite explored.

\subsubsection{Modifications on uridine and 5"-aminoribosyl moieties (subunit A and B)}

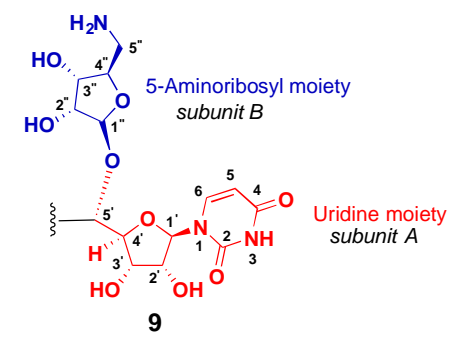

a: Structure of caprazamycin -subunit $A$ and $B$

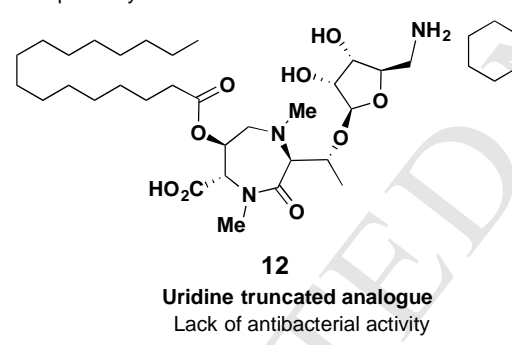

Lack of antibacterial activity

c: Structures of aminoribose/uridine truncated caprazamycin analogues

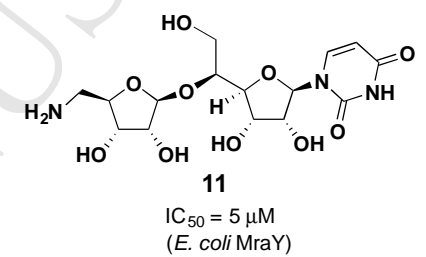

b: Aventis pharmacophoreribosamino-uridines

Figure 3: Modifications on uridine and 5-aminoribosyl moieties (subunit A and B)

Initial studies focussed on probing subunits $A$ and $B$ (9) (Figure 3). The preliminary investigation was carried out by synthesis of $O$ - $\beta$-D-ribofuranosyl nucleoside to evaluate the minimal structural requirement responsible for antibacterial activity against MraY (from Escherichia coli) (SI Table 1) [43]. Following biological evaluation, a moderately active anti-MraY scaffold $\left(\mathbf{1 0}, \mathrm{IC}_{50}=50 \mu \mathrm{M}\right)$ was identified. It was hypothesized that activity could be further improved by introducing a chiral centre in between the two sugars, decreasing conformational flexibility. Accordingly, hydroxymethyl analogues of $O$ - $\beta$-D-ribofuranosyl nucleoside having both the $(R)$ and $(S)$ stereochemistry were designed. Notably, the $S$ isomer (11) was found 10 times more active than the parent structure (10) while the $R$ isomer suffered reduced inhibitory activity. Subsequent investigation found the primary amino group, besides the conservation of uridine, were vital for retaining caprazamycin's activity [44]. Finally, while the 3" hydroxyl proved essential, removal of the $3^{\prime}$ hydroxyl improved antibacterial potency by five-fold relative to the parent scaffold [45]. 

resulted in a complete loss of antibiotic potency against $M$. tuberculosis, highlighting the indispensable nature of both the $5^{\prime \prime}$-aminoribose and uridine functions within the caprazamycin scaffold [46].

\subsubsection{Modifications on diazepanone ring (subunit $C$ )}

The central diazepanone ring in caprazamycin (14, Figure 4) plays a critical anchoring role, orienting the other subunits and facilitating their highly specific interactions within MraY's active site [47]. As the diazepanone ring adds further complexity to synthesis however [48-55], its isosteric substitution with both cyclic and acyclic, or complete removal, are being investigated for use as diazepanone substitutes.

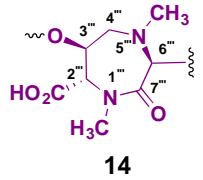

14

1,4-Diazepin-2-one moiety subunit C

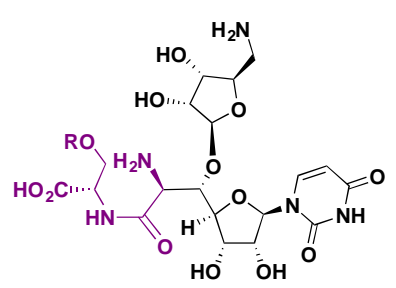

$15 \mathrm{R}=$ Palmitoyl

Staphylococcus. aureus ( $\mathrm{MIC}=25-50 \mu \mathrm{g} / \mathrm{mL}$ ) Micrococcus luteus (MIC $=25-50 \mu \mathrm{g} / \mathrm{mL}$ ) Bacilus subtilis (MIC $=25 \mu \mathrm{g} / \mathrm{mL}$ )

Corynebacterium bovis (MIC $=12.5 \mu \mathrm{g} / \mathrm{mL})$ Enterococcus faecalis (MIC $=50 \mu \mathrm{g} / \mathrm{mL}$ )

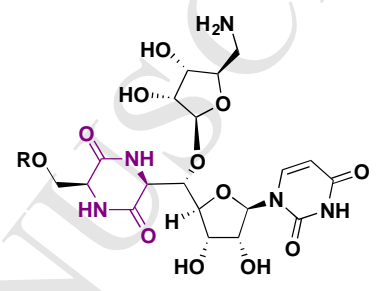

17 R = Palmitoyl

Staphylococcus.aureus (MIC $=25 \mu \mathrm{g} / \mathrm{mL}$ ) Micrococcus luteus (MIC $=25-50 \mu \mathrm{g} / \mathrm{mL}$ ) Bacilus subtilis ( $\mathrm{MIC}=25 \mu \mathrm{g} / \mathrm{mL}$ ) Corynebacterium bovis (MIC $=50 \mu \mathrm{g} / \mathrm{mL}$ )

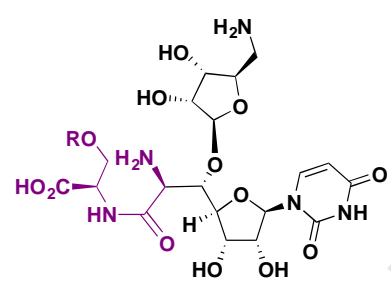

$19 \mathrm{R}=$ Palmitoy

Staphylococcus. aureus (MIC $=25-50 \mu \mathrm{g} / \mathrm{mL}$ ) Micrococcus luteus (MIC $=12.5-50 \mu \mathrm{g} / \mathrm{mL}$ ) Bacilus subtilis (MIC $=25 \mu \mathrm{g} / \mathrm{mL}$ ) Corynebacterium bovis (MIC $=12.5 \mu \mathrm{g} / \mathrm{mL}$ ) Mycobacterium smegmatis (MIC $=50 \mu \mathrm{g} / \mathrm{mL}$ ) Enterococcus faecalis (MIC $=50 \mu \mathrm{g} / \mathrm{mL}$ )

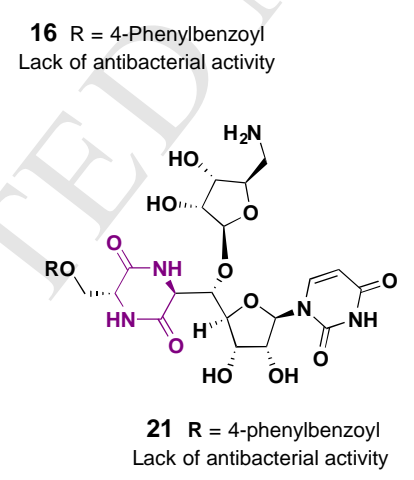

$18 \mathrm{R}=4$-phenylbenzoyl Lack of antibacterial activity

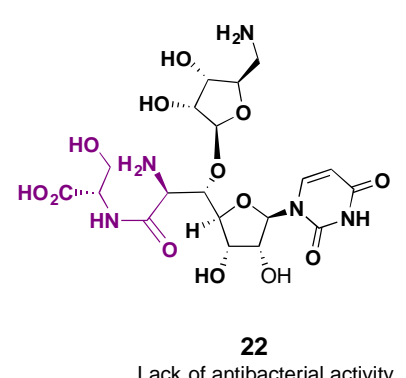

Figure 4: Structures of caprazamycin -subunit $C$ and cyclic/acyclic bioisostere derivatives

211 Matsuda and co-workers investigated relatively simple diketopiperazine motif as a diazepanone 212 substitute (SI Table 2) [47]. Cyclic and acyclic analogues bearing palmitoyl side chains (15, 17,

213 19, Figure 4) exhibited moderate antibacterial activity against Gram-positive bacterial strains (MIC $214=12.5-50 \mu \mathrm{g} / \mathrm{mL}$ ). The reduced activity of substrates $\mathbf{1 5}$ and $\mathbf{1 9}$ was reasoned to be due to their acyclic nature, perhaps not fulfilling the criteria for peripheral subunit orientation. The reduced activity of $\mathbf{1 7}$ was assigned to the absence of the amino and carboxylic acid functionality present in native caprazamycins, groups potentially forming critical interactions with MraY. Compounds 

$100 \mu \mathrm{g} / \mathrm{mL}$ ), likely due to a reduced penetration through the bacterial cell wall. SAR analysis suggested that the cyclic ring, lipophilic side chain, amino and carboxylic acid groups primarily contributed to the antibacterial activity of the parent natural product.

Further investigation into decoding the role of the diazepanone ring led to the generation of acyclic caprazamycin analogues (23-28, Figure 5) lacking in any ring-substitution. These analogues bore the lipophilic side chain linked, either directly or via aryl substitution, to one of either the $C$ - $7^{\prime \prime \prime}$ or $N-5^{\prime \prime \prime}$ positions via either an amide or urea linkage. A diverse array of acyclic analogues were generated including $C$-amide $(\mathbf{2 3}, \mathbf{2 4}), N$-amide $(\mathbf{2 5}, \mathbf{2 6})$ and urea derivatives $(\mathbf{2 7}, \mathbf{2 8})$ (SI Table 3) [56]. The moderate activity of these acyclic analogues demonstrated that the diazepanone ring was not essential - though it was contributing to caprazamycins antibacterial activity. This result further strengthened the diazepanone's proposed role in proper orientation of subsites A, B and D.

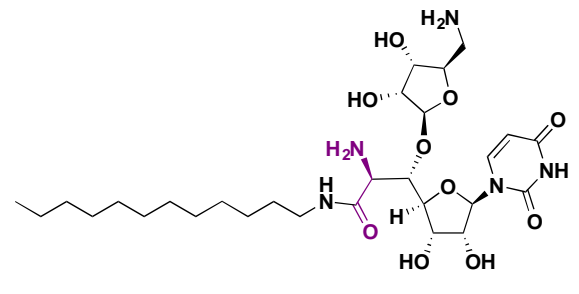

23

$\mathrm{IC}_{50}=18 \mu \mathrm{M}$ (B. subtilis MraY) Enterococci faecalis (MIC $=16 \mu \mathrm{g} / \mathrm{mL}$ ) Enterococci faecalis (VRE) (MIC $=32 \mu \mathrm{g} / \mathrm{mL}$ ) Enterococci facium (MIC $=16 \mu \mathrm{g} / \mathrm{mL}$ ) Enterococci facium (MIC $=16 \mu \mathrm{g} / \mathrm{mL})$
Enterococci faecium (VRE) $(\mathrm{MIC}=16 \mu \mathrm{g} / \mathrm{mL}$ )

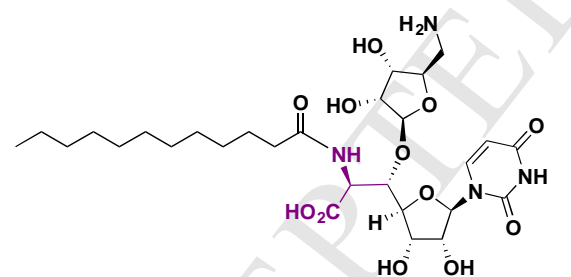

HO

$$
25
$$

$\mathrm{IC}_{50}=63 \mu \mathrm{M}$ (B. subtilis MraY)

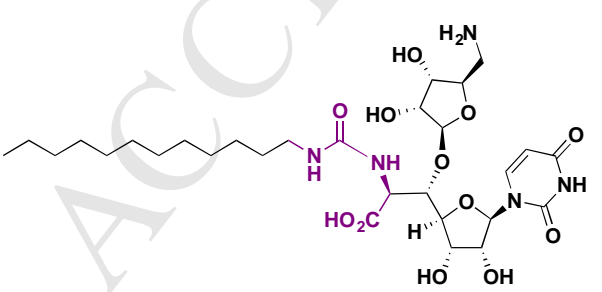

27

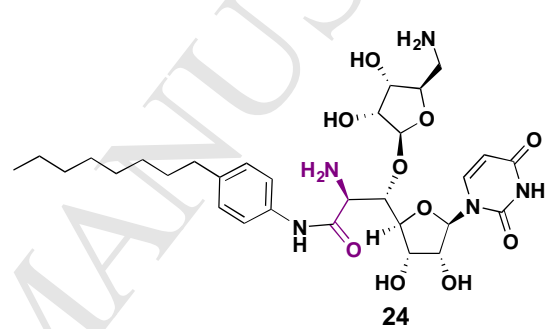

$\mathrm{IC}_{50}=46 \mu \mathrm{M}$ (B. subtilis MraY) Enterococci faecalis (MIC $=16 \mu \mathrm{g} / \mathrm{mL}$ ) Enterococci facium (MIC $=32 \mu \mathrm{g} / \mathrm{mL}$ )
Enterococci faecium (VRE) (MIC $=32 \mu \mathrm{g} / \mathrm{mL}$ )
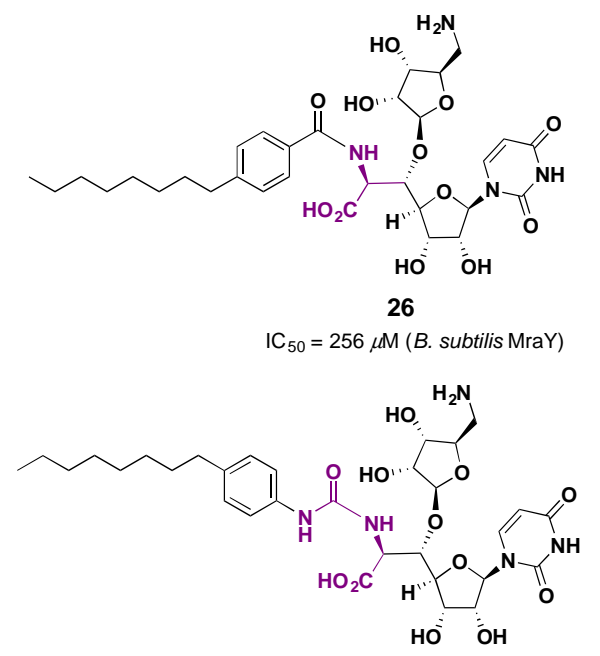

28

$\mathrm{IC}_{50}=75 \mu \mathrm{M}$ (B. subtilis MraY)

Figure 5: Structures of acyclic caprazamycin analogues

Matsuda and co-workers hypothesized that the moderate activity displayed by their acyclic scaffold could be due to their increased flexibility relative to caprazamycin. They therefore aimed to reduce the number of rotatable bonds, thus restricting the number of conformers. To achieve this, the sequential rotatable bonds through N-5"'-C-6"'-C-5'-O-5'-C-1" were incorporated into a single 

orientation simultaneously (Figure 6) (SI Table 4) [56]. Additionally, relatively simple oxazolidine ring system enhanced synthetic accessibility.

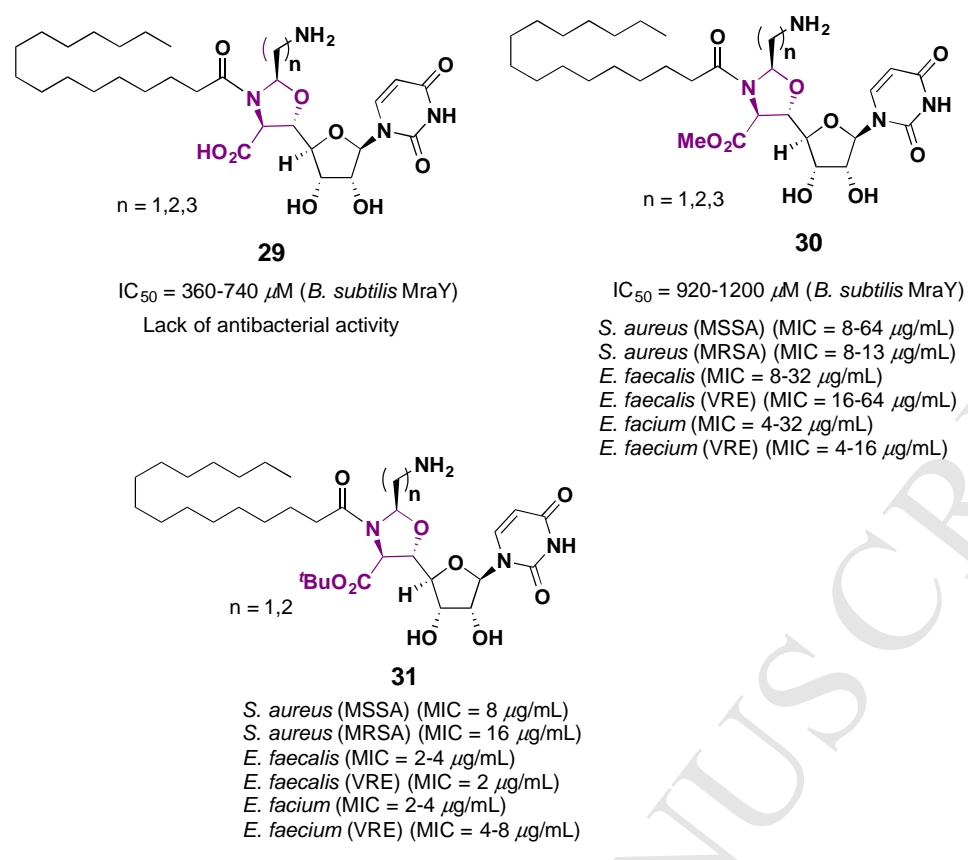

Figure 6: Oxazolidine analogues of caprazamycin natural product

Oxazolidines bearing free carboxylic acids (29) failed to show antibacterial activity (MIC up to 64 $\mu \mathrm{g} / \mathrm{mL}$ ). Analogues $\mathbf{3 0}$ and $\mathbf{3 1}$ exhibited significant antibacterial activity against drug-susceptible Staphylococcus aureus, Enterococcus faecalis and Enterococcus faecium (MIC $=2-64 \mu \mathrm{g} / \mathrm{mL}$ ) as well as drug-resistant bacterial strains such as MRSA and VRE (MIC $=2-64 \mu \mathrm{g} / \mathrm{mL}$ ). Notably, the tert-butyl esters $\mathbf{3 1}$ were the most effective against both the drug-susceptible and drug-resistant Enterococcus faecalis (MIC $=2-4 \mu \mathrm{g} / \mathrm{mL}$ ) with potency like that of desmethylpalmitoylcaprazol. It was suggested that the differences in antibacterial activity between acid $\mathbf{2 9}$ and ester analogues $\mathbf{3 0}$, 31 might be due to their permeability through the bacterial cell membrane. Synthetic azide-bearing intermediates were also evaluated (not depicted) however they suffered from significantly reduced activity, confirming the critical role of the amino functionality. SAR analysis using the functionoriented synthesis [57] suggested the cyclic scaffold, the amino functional group and the lipophilic side chain present in the natural product are very critical. This systematic structural activity study highlighted that the diazepanone ring could be replaced with a simple heterocycle as long as the three essential pharmacophores were oriented appropriately.

Subsequently, Gravier-Pelletier and co-workers introduced structural diversity by introducing a triazole linker in between the $5^{\prime}$ position of aminoribosyl- $O$-uridine and the lipophilic side chain 


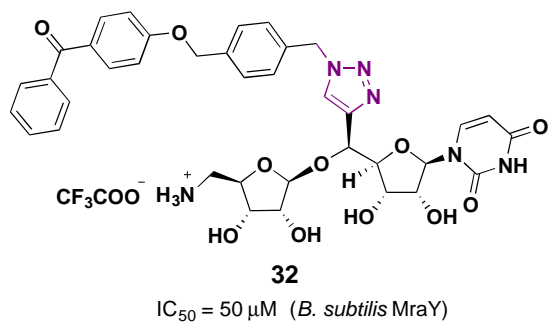

Figure 7: The most potent caprazamycins analogues from the series of triazoles
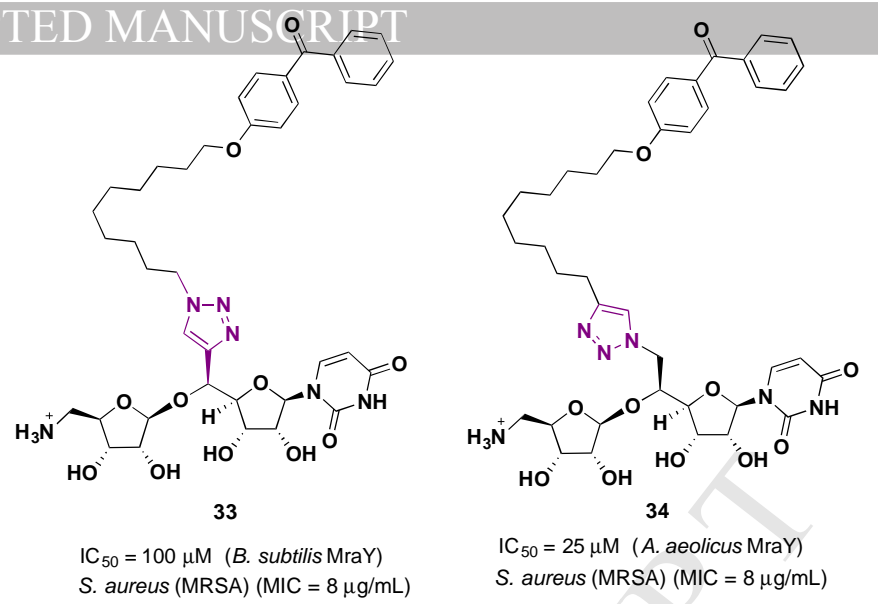

All of the synthesized compounds with benzophenone-substituted side chains exhibited moderate inhibitory activity against MraY enzyme (from Bacillus subtilis) $\left(\mathrm{IC}_{50}=50-125 \mu \mathrm{M}\right)$. Their second-generation $5^{\prime}$-methylene triazole analogues (e.g. 34, Figure 7), linked through either a $C$ - or $N$-triazole, possessed increased flexibility due to presence of an additional methylene group, proposed to aid their positioning within MraY's active site (MraY from Bacillus subtilis) (SI Table 6) [59]. Of their initial library of 5'-triazoles, their most effective inhibitors contained either a benzophenone moiety (e.g. 32, $\mathrm{IC}_{50}=50-125 \mu \mathrm{M}$ ) or an alkyl chain (not depicted) $\left(\mathrm{IC}_{50}=140-150\right.$ $\mu \mathrm{M})$. A shorter alkyl chain bearing a polar functional group exhibited decreased inhibitory activity against MraY (from Bacillus subtilis) $\left(\mathrm{IC}_{50}>1000 \mu \mathrm{M}\right)$. It was interesting to note that the antiMraY activity could be improved by increasing the length of the hydrophobic side chain. The inhibition was competitive as well as irreversible against the nucleotide substrate.

Both the 5'-methylene linked $C$ - and $N$-triazole-containing analogues were found to be more effective inhibitors than directly linked 5'-triazoles, with 5'-methylene linked $C$-triazoles exhibiting the most potent activity. Notably, an increase in the length of the hydrophobic chain on either of the 5 -methylene linked $C$ - or $N$-triazoles correlated with increased anti-MraY activity (MraY from Bacillus subtilis) $\left(\mathrm{IC}_{50}=15-25 \mu \mathrm{M}\right.$ for 5'-methylene linked $C$-triazoles, $25-100 \mu \mathrm{M}$ for $5^{\prime}$ methylene linked $N$-triazoles). As observed previously [58], the presence of a bulky benzophenone group was well tolerated with analogues exhibiting promising inhibitory activity $\left(\mathrm{IC}_{50}=20-25 \mu \mathrm{M}\right.$ for $5^{\prime}$-methylene linked $C$-triazoles, $25-100 \mu \mathrm{M}$ for $5^{\prime}$-methylene linked $N$-triazoles). During in cellulo studies against Gram-positive and Gram-negative pathogens, 9 compounds from a library of 33 were found to have antibacterial activity ( $\mathrm{MIC}=8-64 \mu \mathrm{g} / \mathrm{mL}$ ) against three Gram-positive and Gram-negative Pseudomonas aeruginosa. Decycloxybenzophenone functionalised triazoles exhibited the most potent antibacterial activity $\left(33, \mathrm{IC}_{50}=100 \mu \mathrm{M}, \mathrm{MIC}=8 \mu \mathrm{g} / \mathrm{mL} ; \mathbf{3 4}, \mathrm{IC}_{50}=25\right.$ $\mu \mathrm{M}$, MIC $=8 \mu \mathrm{g} / \mathrm{mL}$ ) against Staphylococcus aureus MRSA from the series of all synthesized triazoles (Figure 7). It was interesting to note that although the triazoles were not as structurally 
complex, their antibacterial activity was comparable with the natural nucleoside antibiotic MraY inhibitor muraymycin [60].

Matsuda and co-workers employed a scaffold hopping approach to identify the isoxazolidine ring system as an isosteric replacement for the diazepanone and aminoribose moieties (SI Table 7) [6162]. A series of isoxazolidine analogues decorated with the critical aminoalkyl and fatty acyl motifs were evaluated against a range of bacterial pathogens. Synthetic analogue 35, containing opposite stereochemistry to caprazamycins at the 5'-position, was found to be inactive against all the evaluated bacterial strains except for Haemophilus influenzae ATCC 10211 (MIC = $1 \mu \mathrm{g} / \mathrm{mL}$ ). Analogue 36, retaining the same stereochemistry as the natural product, displayed significant antibacterial activity against Haemophilus influenzae ATCC $10211(\mathrm{MIC}=0.25-0.5 \mu \mathrm{g} / \mathrm{mL})$ and moderate activity against vancomycin resistant Enterococcus faecalis $\mathrm{SR} 7914$ (MIC $=4-8 \mu \mathrm{g} / \mathrm{mL}$ ) (Figure 8). This study demonstrates effectively the contribution made by the 5'-positions' stereochemical configuration to its antibiotic properties.

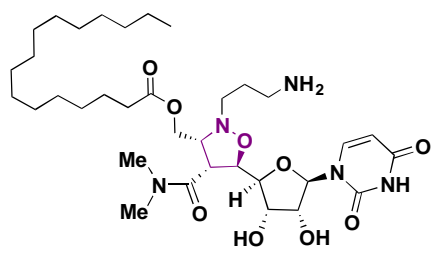

35

H. influenzae $(\mathrm{MIC}=1 \mu \mathrm{g} / \mathrm{mL})$

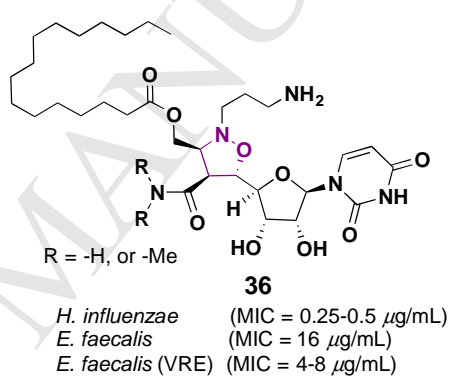

Figure 8: Structures of isoxazolidine-containing caprazamycin analogues

The fact that anti-MraY activity was reported to tolerate a simpler isoxazolidine scaffold encouraged the design of simpler analogues. In continuation of the efforts to explore simpler yet bioequivalent scaffolds, Ichikawa and co-workers synthesized uridine analogues containing a six membered piperidine scaffold (Figure 9) (SI Table 8) [63]. This piperidine scaffold facilitated investigation into the importance of the caprazamycins stereochemistry at the diazepanone's C-6" and at the uridine's C-5'. Additionally, it was proposed that the more constrained six member ring, relative to caprazamycins seven-member diazepanone ring, might translate to an increased activity against MraY due to the fewer possible conformational isomers. Finally, the piperidine scaffold is significantly more synthetically accessible. Following synthesis of a library of piperidine-based analogues, inhibitory activity against purified MraY (from Staphylococcus aureus) was evaluated in a fluorescence-based MraY assay [64]. It was observed that the piperidine analogues 37 and 38, with opposite stereochemistry at C-5' to caprazamycin, were found to be weak inhibitors ( $\mathrm{IC}_{50}$ value $>2700 \mathrm{nM})$. The remaining analogues with the same stereochemistry at C-5'(39 and 40), exhibited good inhibitory activity. Substrate 39, which retained the natural products' $6{ }^{\prime \prime \prime} R$ chirality, was found to be 8.6-fold stronger $\left(\mathrm{IC}_{50}=24 \mathrm{nM}\right)$ than its diastereomer $\mathbf{4 0}\left(\mathrm{IC}_{50}=206 \mathrm{nM}\right)$. The strong 

ring to the six-membered piperidine scaffold.

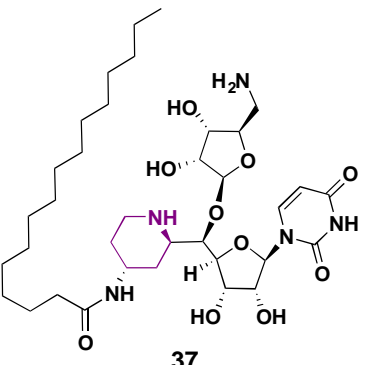

$\mathrm{IC}_{50}=>2700 \mathrm{~nm}$ (S. aureus MraY) S. aureus $(\mathrm{MSSA}) \quad(\mathrm{MIC}=16 \mu \mathrm{g} / \mathrm{mL})$ S. aureus (MRSA) (MIC $=32 \mu \mathrm{g} / \mathrm{mL})$

$\begin{array}{ll}\text { E. faecalis } & (\mathrm{MIC}=32 \mu \mathrm{g} / \mathrm{mL})\end{array}$

$\begin{array}{ll}\text { E. faecalis } & (\mathrm{MIC}=32 \mu \mathrm{g} / \mathrm{mL}) \\ \text { E. faecalis (VRE) } & (\mathrm{MIC}=32 \mu \mathrm{g} / \mathrm{mL})\end{array}$

$\begin{array}{ll}\text { E. faecalis (VRE) } & (\mathrm{MIC}=32 \mu \mathrm{g} / \mathrm{mL}) \\ \text { E. faecium } & (\mathrm{MIC}=32 \mu \mathrm{g} / \mathrm{mL})\end{array}$

E. faecium (VRE) (MIC $=16 \mu \mathrm{g} / \mathrm{mL}$ )

$\begin{array}{ll}\text { E. coli } & (\mathrm{MIC}=32 \mu \mathrm{g} / \mathrm{mL} \text { ) }\end{array}$

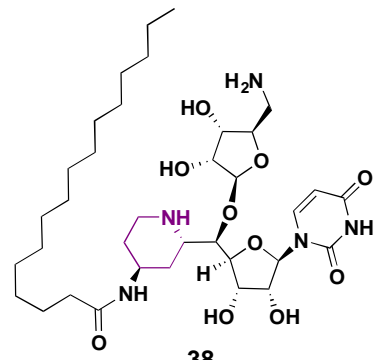

38

$\mathrm{IC}_{50}=>2700 \mathrm{~nm}$ (S. aureus MraY)

S. aureus (MSSA) $(\mathrm{MIC}=8 \mu \mathrm{g} / \mathrm{mL})$

S. aureus (MRSA) (MIC $=16 \mu \mathrm{g} / \mathrm{mL})$

$\begin{array}{ll}\text { S. aureus (MRSA) } & (\mathrm{MIC}=16 \mu \mathrm{g} / \mathrm{mL}) \\ \text { E. faecalis } & (\mathrm{MIC}=16 \mu \mathrm{g} / \mathrm{mL})\end{array}$

$\begin{array}{ll}\text { E. faecalis } & (\mathrm{MIC}=16 \mu \mathrm{g} / \mathrm{mL}) \\ \text { E. faecalis (VRE) } & (\mathrm{MIC}=16 \mu \mathrm{g} / \mathrm{mL})\end{array}$

$\begin{array}{ll}\text { E. faecalis (VRE) } & (\mathrm{MIC}=16 \mu \mathrm{g} / \mathrm{mL}) \\ \text { E. faecium } & (\mathrm{MIC}=32 \mu \mathrm{g} / \mathrm{mL})\end{array}$

$\begin{array}{ll}\text { E. faecium } & (\mathrm{MIC}=32 \mu \mathrm{g} / \mathrm{mL}) \\ \text { E. faecium (VRE) } & (\mathrm{MIC}=8 \mu \mathrm{g} / \mathrm{mL})\end{array}$

$\begin{array}{ll}\text { E. coli } & \text { (MIC }=32 \mu \mathrm{g} / \mathrm{mL} \text { ) }\end{array}$

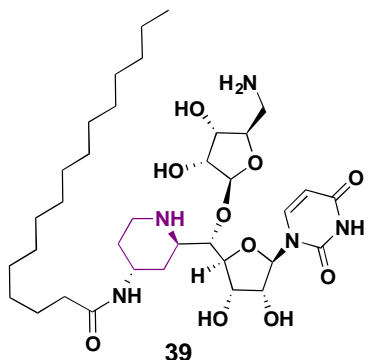

$\mathrm{IC}_{50}=24 \mathrm{~nm}$ (S. aureus MraY) S. aureus (MSSA) (MIC $=8 \mu \mathrm{g} / \mathrm{mL})$ $\begin{array}{ll}S . & \text { aureus (MSSA) } \\ \text { S. } & \text { aureus (MRSA) }=8 \mu \mathrm{g} / \mathrm{mL}) \\ (\mathrm{MIC}=16 \mu \mathrm{g} / \mathrm{mL})\end{array}$ $\begin{array}{ll}\text { S. aureus (MRSA) } & (\mathrm{MIC}=16 \mu \mathrm{g} / \mathrm{mL}) \\ \text { E. faecalis } & \text { (MIC }=4 \mu \mathrm{mL})\end{array}$ E. faecalis (VRE) (MIC $=2 \mu \mathrm{g} / \mathrm{mL}$ ) $\begin{array}{ll}\text { E. faecalis (VRE) } & (\mathrm{MIC}=2 \mu \mathrm{g} / \mathrm{mL}) \\ \text { E. faecium } & \text { (MIC }=8 \mu \mathrm{g} / \mathrm{mL})\end{array}$ $\begin{array}{ll}\text { E. faecium } & (\mathrm{MIC}=8 \mu \mathrm{g} / \mathrm{mL}) \\ \text { E. faecium } & \text { (VRE) } \\ \text { (MIC }=4 \mu \mathrm{mL}\end{array}$ $\begin{array}{ll}\text { E. faecium (VRE) } & (\mathrm{MIC}=4 \mu \mathrm{g} / \mathrm{mL}) \\ \text { H. influenzae } & \text { (MIC }=32 \mu \mathrm{g} / \mathrm{mL})\end{array}$ $\begin{array}{ll}H \text {. influenzae } & (\mathrm{MIC}=32 \mu \mathrm{g} / \mathrm{mL}) \\ P . \text { aeruginosa } & (\mathrm{MIC}=32 \mu \mathrm{g} / \mathrm{mL})\end{array}$

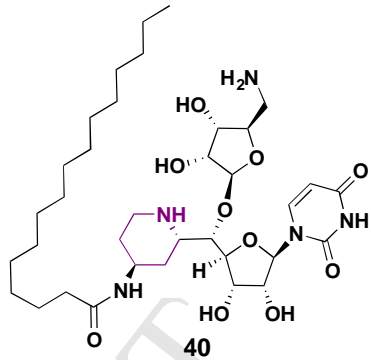

$\mathrm{IC}_{50}=206 \mathrm{~nm}$ (S. aureus MraY)

S. aureus $(\mathrm{MSSA}) \quad(\mathrm{MIC}=8 \mu \mathrm{g} / \mathrm{mL})$ S. aureus (MRSA) (MIC $=8 \mu \mathrm{g} / \mathrm{mL})$ E. faecalis $\quad(\mathrm{MIC}=8 \mu \mathrm{g} / \mathrm{mL})$ E. faecalis (VRE) $\quad(\mathrm{MIC}=8 \mu \mathrm{g} / \mathrm{mL})$ E. faecium $\quad(\mathrm{MIC}=8 \mu \mathrm{g} / \mathrm{mL})$ E. faecium (VRE) $\quad(\mathrm{MIC}=4 \mu \mathrm{g} / \mathrm{mL})$ E. coli $\quad(\mathrm{MIC}=16 \mu \mathrm{g} / \mathrm{mL}$ ) $\begin{array}{ll}\text { H. influenzae } & (\mathrm{MIC}=32 \mu \mathrm{g} / \mathrm{mL} \text { ) } \\ \text { P. aeruginosa } & (\mathrm{MIC}=32 \mu \mathrm{g} / \mathrm{mL})\end{array}$

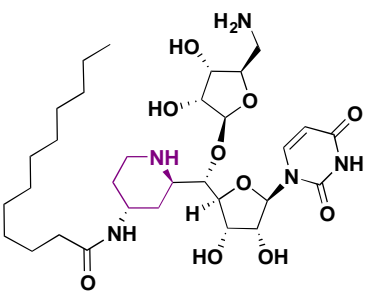

41

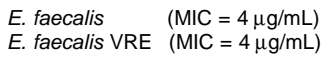

E. faecalis VRE (MIC $=4 \mu \mathrm{g} / \mathrm{mL})$

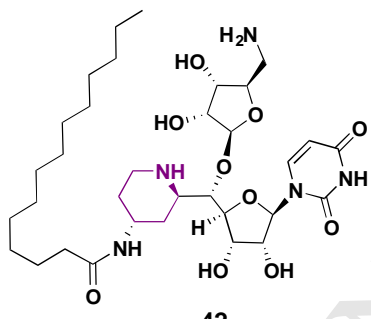

42

S. aureus $(\mathrm{MSSA}) \quad(\mathrm{MIC}=16 \mu \mathrm{g} / \mathrm{mL})$ $\begin{array}{ll}\text { S. aureus (MSSA) } & (\mathrm{MIC}=16 \mu \mathrm{g} / \mathrm{mL}) \\ \text { S. aureus (MRSA) } & (\mathrm{MIC}=32 \mu \mathrm{g} / \mathrm{mL})\end{array}$ E. faecalis $\quad(\mathrm{MIC}=2 \mu \mathrm{g} / \mathrm{mL})$ E. faecalis (VRE) $\quad(\mathrm{MIC}=2 \mu \mathrm{g} / \mathrm{mL})$ $\begin{array}{ll}\text { E. faecium } & \text { (MIC }=16 \mu \mathrm{g} / \mathrm{mL}) \\ \text { E. faecium (VRE) } & \text { (MIC }=8 \mu \mathrm{g} / \mathrm{mL})\end{array}$ $\begin{array}{ll}\text { E. faecium (VRE) } & (\mathrm{MIC}=8 \mu \mathrm{g} / \mathrm{mL}) \\ \text { H. influenzae } & (\mathrm{MIC}=32 \mu \mathrm{g} / \mathrm{mL})\end{array}$ $\begin{array}{ll}\text { H. influenzae } & (\mathrm{MIC}=32 \mu \mathrm{g} / \mathrm{mL}) \\ P . \text { aeruginosa } & (\mathrm{MIC}=32 \mu \mathrm{g} / \mathrm{mL})\end{array}$

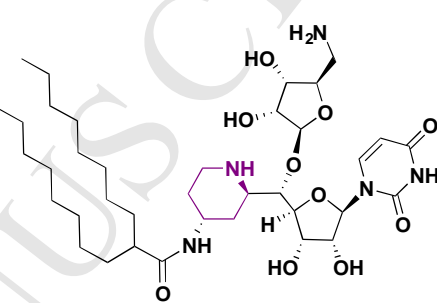

43

S. aureus (MSSA) $\quad(\mathrm{MIC}=4 \mu \mathrm{g} / \mathrm{mL}$ ) S. aureus (MRSA) (MIC $=8 \mu \mathrm{g} / \mathrm{mL})$ $\begin{array}{ll}\text { E. faecalis } & (\mathrm{MIC}=4 \mu \mathrm{g} / \mathrm{mL})\end{array}$ E. faecalis (VRE) $\quad(\mathrm{MIC}=4 \mu \mathrm{g} / \mathrm{mL})$ E. facium (VRE) (MIC $=4 \mu \mathrm{g} / \mathrm{mL})$ S. pneumoniae (I) (MIC $=8 \mu \mathrm{g} / \mathrm{mL}$ ) S. pneumoniae (I) (MIC $=32 \mu \mathrm{g} / \mathrm{mL})$ $\begin{array}{ll}\text { H. influenzae } & (\mathrm{MIC}=16 \mu \mathrm{g} / \mathrm{mL}) \\ P . \text { aeruginosa } & (\mathrm{MIC}=16 \mu \mathrm{g} / \mathrm{mL})\end{array}$

Figure 9: Structures of piperidinyl analogues of caprazamycins

Piperidine-based acetate-containing analogues (not depicted) (SI Table 8) failed to show any evidence of MraY (from Staphylococcus aureus) activity, suggesting lipophilicity played a significant role in enzyme inhibition. Substrates boasting a palmitoyl group as lipophilic side chain (37-40) exhibited significant antibacterial activity against a range of Gram-positive bacterial strains such as Staphylococcus aureus SR3637 (MRSA) and Enterococcus faecium SR7917 (VRE) (MIC = 2-32 $\mu \mathrm{g} / \mathrm{mL}$ ). Similar trends of enzyme inhibition were observed regarding antibacterial activity, with $5^{\prime} S$ isomeric substrates 39 and $40(\mathrm{MIC}=2-16 \mu \mathrm{g} / \mathrm{mL})$ exhibiting increased activity over the $5^{\prime} R$ analogue, 37 and $38(\mathrm{MIC}=8-32 \mu \mathrm{g} / \mathrm{mL})$. Once more, analogue 39, retaining both $6^{\prime \prime \prime} R$ and $5^{\prime} S$ natural product stereochemistry, exhibited the strongest antibacterial activity (MIC 2-16 $\mu \mathrm{g} / \mathrm{mL}$ ). Subsequent examinations of 39's metabolic stability showed it was unaffected by human or mouse liver microsomes. These compounds were found cytotoxic against human hepatocellular liver carcinoma (HepG2) cells $\left(\mathrm{IC}_{50}=23\right.$ to $\left.35 \mu \mathrm{M}\right)$ however, limiting their utility.

The observed cytotoxicity was presumed to be due to the increased hydrophobicity incurred from truncating polar functional groups such as the carboxylic acid and the amide group. To resolve this, Ichikawa and co-workers designed model compounds bearing shorter lipophilic groups such as 
lauroyl (41) and myristoyl groups (42) (Figure 9) (SI Table 9) [63]. They also speculated that toxicity was due to micelle formation and so, to reduce the likelihood of micelle formation, analogues with branched lipophilic side chains 43 were designed (SI Table 9). Analogues 41 and 42, bearing shorter lipophilic side chains, displayed decreased activity relative to the palmitoylcontaining parent compound 39. The branched chain analogues (e.g. 43) retained their antibacterial activity against Gram-positive bacterial strains (MIC $=4$ to $8 \mu \mathrm{g} / \mathrm{mL}$ ) however, while also showing a complete loss of cytotoxicity against HepG2 cells up to $100 \mu \mathrm{M}$. Author suggested that though further optimization is essential for evaluating impact of branching on toxicity, the branched analogue $\mathbf{4 3}$ could be a lead structure because of its high therapeutic index. This study demonstrates the successful transformation from the diazepanone to a simplified piperidine ring while also highlighting the importance of the stereochemistry at the C-5' and C-6'" positions.

In an attempt to improve the practicality of their synthesis, Ichikawa and co-workers designed additional, simplified caprazamycin analogues aided by their implemented function-oriented synthesis (FOS) strategy [57]. They propose that the function of structurally complex natural products can be mimicked or even improved upon by appropriately linking the essential structural components through simpler structural entities. Synthetic accessibility can then be prioritised, facilitating the construction of larger analogue libraries promising an enriched perspective on the natural product's SARs. By applying FOS principles, the researchers designed and synthesized diverse analogues of lactam-fused isooxazolidine core structures (SI Table 10) [65]. Such a scaffold permitted modulation of the three-dimensional orientation of key structural units, either by alteration of stereochemistry or by modifying the size of the ring.

Two types of lactam-fused isoxazolidine derivatives were investigated: the first bearing a linear substituent linking the lipophilic side chain with an accessory arginine group (Type I), and the second, a branched variant with each substituent anchored to the central lactam ring (Type II) (e.g. 44, Figure 10) [65].

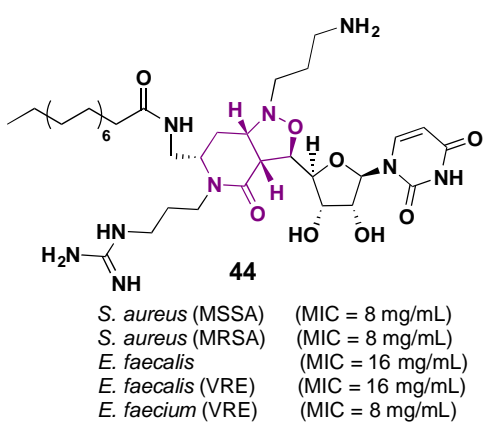

Figure 10: The most active structure from a series of lactam-fused isoxazolidines

Generally, many lactam-fused isooxazolidine analogues exhibited moderate activity against a range of Gram-positive drug-resistant bacterial strains including Staphylococcus aureus SR3637 (MRSA) 
(Type II) boasted increased activity over linearly substituted (Type I) compounds. Amongst all the synthesised lactam-fused isooxazolidines, compound $\mathbf{4 4}$ was found to be the most potent analogue

(Figure 10).

4.2.3. Modifications on western zone fatty acyl chain (subunit D)

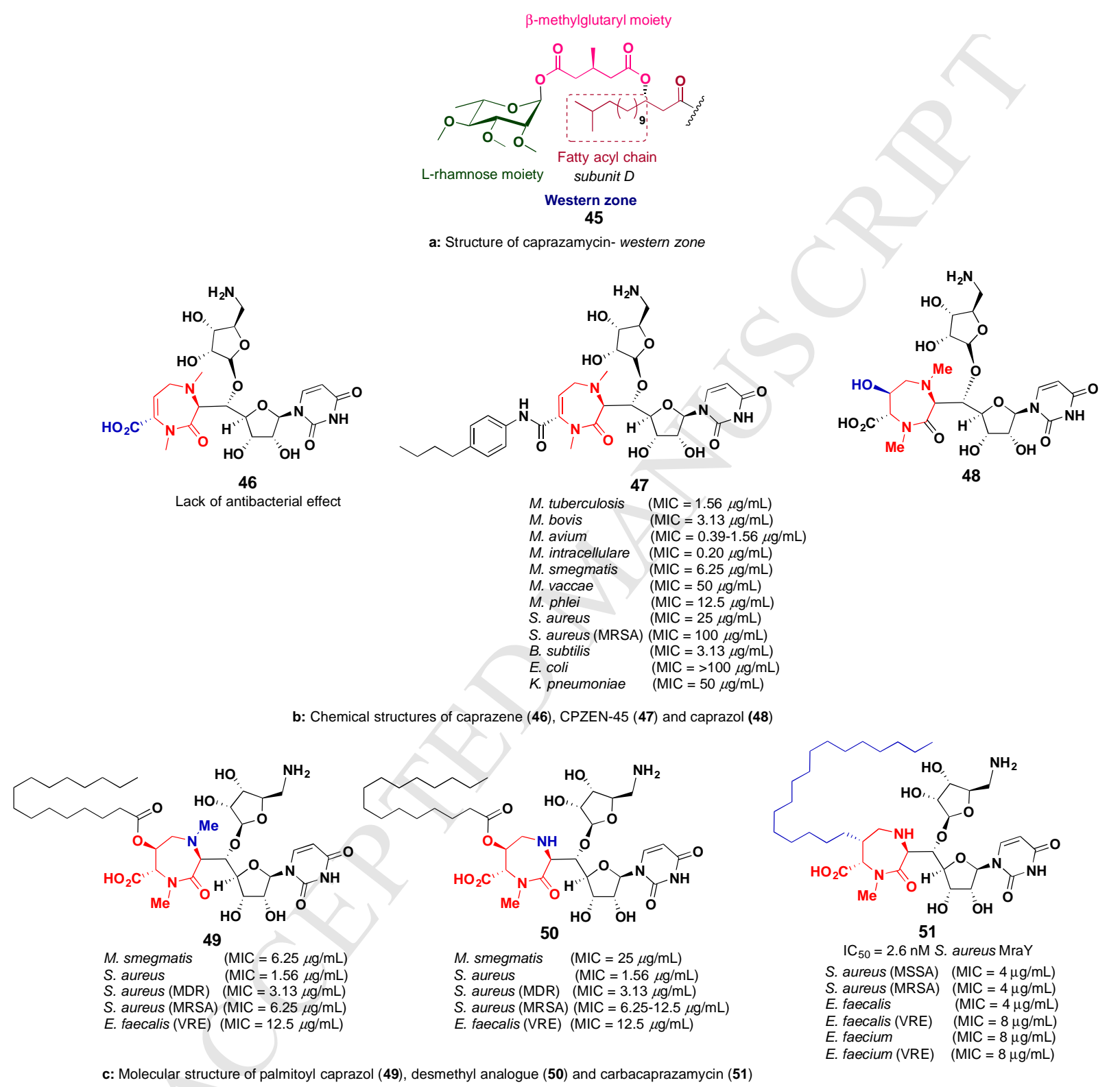

Figure 11: Modifications on western zone fatty acyl chain (subunit D)

371 Caprazamycins western zone is composed of three structural subunits - a fatty acyl moiety, a 3methylglutaric acid tether and an $O$-methylated-L-rhamnoside (Figure 11) [39]. The naturally occurring caprazamycins are classified into seven analogues (CPZ A-G) according to their structural diversity within western zones. Though highly potent, their limited sourcing from nature necessitates investigation into the SARs of potent semisynthetic analogues to aid identification of eligible drug candidates. Furthermore, difficulties arise when investigating the natural 
caprazamycins because of their challenging isolation from complex mixtures. Adding further complexity to the endeavour, conventional methods (e.g. high-performance liquid chromatography, HPLC) aren't reliable within this context because of the caprazamycins' poor water-solubility profile, due in part to their western zone. Due to its complex nature, modulation or replacement of the western zone is an appealing strategy.

One such strategy circumventing this entire issue was to treat the complex mixture of natural caprazamycins with an acid to afford caprazene (CPZEN) (46), made up of subunits A, B and C (Figure 11) [12]. Though its isolation from the complex mixture of natural products was drastically simplified, the absence of any fatty acyl moiety in caprazene rendered it biologically inactive. Following isolation, functionalisation at the diazepinone with some lipophilic chain was expected to restore antibacterial activity [12]. Substitution at the 5"-amino group of D-ribose was also considered, however the location of the carboxylic acid group was preferred due to its position adjacent to the native fatty acyl linkage site. Besides that, the availability of the free amino group afforded some control over water solubility via acid salt formation. Semisynthetic caprazamycin analogues bearing 1"'"-alkylamide, 1'"'-anilide and 1'"'-ester substitutions were generated and evaluated subsequently (SI Table 11).

From the series of semi-synthetic caprazamycin analogues, the 4-butylanilide substituted derivative of caprazene (CPZEN-45, 47) was identified to be the most active inhibitor (Figure 11). It displayed superior inhibition over the natural product CPZ-B (2) with excellent activity against diverse Mycobacterium strains $(\mathrm{MIC}=0.20-50 \mu \mathrm{g} / \mathrm{ml}$ ). However, the reduction of antibacterial activity of CPZEN derivatives against various Gram-positive and Gram-negative bacterial strains $(\mathrm{MIC}=3.13-100 \mu \mathrm{g} / \mathrm{mL})$ in comparison with caprazamycin B (2) reflected their obvious difference in selectivity toward a bacterial spectrum. Further investigation confirmed that unlike natural caprazamycin, the caprazene derivatives inhibit WecA enzyme, which is involved in biosynthesis of mycolyl arabinogalactan [66]. Since long-term chemotherapy is required for TB treatment, the CPZEN derivatives were studied for selectivity, specificity and a narrow-range antimicrobial spectrum to evaluate their suitability for extended therapy. CPZEN-45 (47) was found to be the most active CPZEN derivative, with an $\mathrm{MIC}$ range, $\mathrm{MIC}_{50}$ and $\mathrm{MIC}_{90}$ for drug-sensitive Mycobacterium tuberculosis clinical isolates of $0.78-12.5,1.56$ and $3.13 \mu \mathrm{g} / \mathrm{ml}$, respectively. Moreover, the selectivity, negligible haemolysis and excellent water solubility of $\mathbf{4 7}$ qualified it as a promising lead in clinical trials for use as both a new anti-TB and a novel anti-MAC agent [13, 67]. As acid-catalysed hydrolysis of caprazamycin yielded caprazene analogues, base-catalysed hydrolysis of natural product afforded biologically inactive caprazol (48) (Figure 11). 
To restore the antibacterial activity of caprazol (48) a simple palmitoyl residue was introduced as the lipophilic side chain, generating palmitoyl caprazol 49 (Figure 11) (SI Table 12) [9]. Compound 49 exhibited significant antibacterial activity against Mycobacterium smegmatis (MIC = $6.25 \mu \mathrm{g} / \mathrm{mL}$ ) with a potency in the range of the caprazamycins. Absence of the methyl group at the $N-5^{\prime \prime \prime}$-position, as in the case of desmethyl palmitoyl caprazol 50, led to a 4-fold reduction in antibacterial potency $(\mathrm{MIC}=25 \mu \mathrm{g} / \mathrm{mL})$. The observed reduction of antibacterial activity might be due to the difference in lipophilicity contributed by the methyl group (SI Table 12). The author suggested that the lipophilic nature of the molecule might be essential for its permeation through the exceptionally thick and tight mycobacteria cell wall. However, unlike Mycobacterium smegmatis, both 49 and $\mathbf{5 0}$ exhibited similar potency against drug resistant bacteria such as MRSA and VRE strains $(\mathrm{MIC}=3.13-12.5 \mu \mathrm{g} / \mathrm{mL}$ ). This study demonstrated the successful replacement of the complex substituents and stereocenters of the western zone with a simple palmitoyl substitution. Further precise optimization of the lipophilic side chain could promote permeation through bacterial cells.

Though the palmitoylcaprazol scaffold afforded strong potency, palmitoyl caprazol (49) was not considered a viable lead structure due to its complex synthesis and its $\beta$-acyloxy ester linkage, a function speculated to hinder metabolic stability via $\beta$-elimination. To overcome this instability, 'carbacaprazamycin' analogues [e.g. 51 (Figure 11)], functionalised with hydrophobic chains linked directly to the diazepanone via C-C bonding, were designed (SI Table 13) [68]. Both epimers, differing at the 3"' position of diazepanone ring, were employed to probe the chiral centres influence on bioactivity. Evaluation against MraY (from Staphylococcus aureus) during a fluorescence-based MraY assay [64] suggested that the carbacaprazamycins retained strong MraY inhibitory activity $\left(\mathrm{IC}_{50}=2.6-6.9 \mathrm{nM}\right)$. Subsequent antibacterial evaluation highlighted the moderate potency of carbacaprazamycins against drug-resistant bacterial pathogens such as MRSA and VRE $(\mathrm{MIC}=4-16 \mu \mathrm{g} / \mathrm{mL})$. In both the cases of enzymatic inhibition $\left(\mathrm{IC}_{50}=2.6-6.9 \mathrm{nM}\right)$ and antibacterial activity $(\mathrm{MIC}=4-16 \mu \mathrm{g} / \mathrm{mL})$, the carbacaprazamycins were found 4-6 times less effective than the palmitoylcaprazole $\left(\mathrm{IC}_{50}=1.2 \mathrm{nM}\right.$, MIC $=0.5-2 \mu \mathrm{g} / \mathrm{mL}$ ) however this was speculated to be due to the replacement of the ester moiety, increasing the lipophilicity of entire molecule. Once more, methyl substitution at $\mathrm{N}-5^{\prime \prime \prime}$ of carbacaprazamycin translated to an improved potency relative to the desmethyl analogue $(4-8 \mu \mathrm{g} / \mathrm{mL}$ vs $8-16 \mu \mathrm{g} / \mathrm{mL})$, a trend correlating with previous results from the palmitoylcaprazole study (SI Table 13) [9]. Interestingly, epimer 51 ( $S$ configuration, $\mathrm{MIC}=4-8 \mu \mathrm{g} / \mathrm{mL}$ ), possessing unnatural stereochemistry the $3^{\prime \prime \prime}$ position, displayed an increased activity relative to that of the epimer reflecting the native stereochemistry $(R$ 
configuration, MIC $=8-16 \mu \mathrm{g} / \mathrm{mL})$. The author suggested further optimization of the lipophilic side chain to increase the antibacterial activity of carbacaprazamycins.

Research pursuit to enrich our understanding of caprazamycins' anti-MraY activity has resulted in the generation of potent, broad-spectrum antibiotics. Their promising antibiotic properties have qualified caprazamycin analogues as platforms upon which potent drug-like scaffolds may be designed and optimised. SAR-based analysis of the critical pharmacophores has proved invaluable in this endeavour. Herein, we have compiled the trends that should be considered when aiming to improve bioactivity and drug likeness: $i$ ) conservation of both uridine and 5"-aminoribose structures is essential $[43,46]$; ii) stereochemistry at both C-5' and C- $6^{\prime \prime \prime}$ positions must be considered [6263]; iii) a cyclic core orienting the key subunits in specific stereochemical arrangement is essential $[47,56] ; i v)$ regarding the core cycle, simpler rings than the complex diazepanone are well tolerated $[47,56,58-59,62-63,65] ; v)$ the western zone, though structurally complex in the natural caprazamycins, can be replaced by simple lipophilic side chain $[9,12,68]$.

\section{Concluding remarks}

The global status of antimicrobial resistance amongst currently employed agents outlines the need to explore novel targets for antibacterial action. Bacterial cell wall biosynthesis has been heavily exploited since the discovery of penicillin [6]. Despite having promising activity for bacterial cell wall inhibitors, in the present era of increasing resistance there is a need to explore novel targets which will translate to extended drug utility before resistance develops. Indeed, most of the enzymes involved in peptidoglycan biosynthesis have been targeted by clinical antibiotics, except the translocase I enzyme (MraY). MraY as an antibacterial target has gained research interest in the past few years due to the existence of diverse nucleoside antibiotics that act specifically $[14,19]$. Naturally occurring nucleoside antibiotics have not yet proved useful within the clinical context however, mainly due to the lack of three-dimensional structural insight into the inhibition of MraY. Recently, structural determination of the MraY enzyme, along with its complex with natural nucleoside antibiotics, has opened possibilities for structure-based drug design against MraY [27, 34, 69].

Unlike existing cell wall inhibitors (i.e. penicillins), nucleoside antibiotics (capuramycin analogues) have shown bactericidal activity against nonreplicating (dormant) Mycobacterium TB [70]. Caprazamycins as a subclass of nucleoside antibiotics have exhibited a wide range of in vitro anti-mycobacterial activity against both drug-susceptible and multi drug-resistant Mycobacterium TB strains without conferring toxicity in mice [37]. One semisynthetic caprazamycin analogue (CPZEN-45) is under preclinical study for antitubercular activity [67]. Additionally, the caprazamycins class of nucleoside antibiotics have also shown their promising activity against 
diverse Gram-positive strains including both drug-sensitive as well as drug resistant MRSA and VRE. Their antibiotic properties also include their potent activity against Gram-negative bacterial strains such as Pseudomonas aeruginosa and Haemophilus influenzae. With these excellent antibiotic properties against both Gram-positive as well as Gram-negative bacterial strains, caprazamycins are expected to be a promising lead structures for development of broad-spectrum antibacterial agent. This SAR (see SI Figure 2) study was carried out to reveal the essential pharmacophores present in the natural caprazamycin scaffold. We hope this work will contribute to the development of urgently required novel antibacterial agents.

\section{Appendix A. An example appendix}

\section{A.1. Example of a sub-heading within an appendix}

\section{Supplementary Material}

Detailed information on antimicrobial profile of synthetic caprazamycin derivatives is available on the Journal's website.

\section{Conflicts of Interest}

The authors declare no conflicts of interest.

\section{Acknowledgements}

Financial support to SR from an Australian Research Council - Discovery Early Career Research Award (DE140101632) is gratefully acknowledged. SR expresses his sincere gratitude to Professor Richard J. Payne and Professor Kate Jolliffe (The University of Sydney) for their support. BP is supported by Griffith University Postgraduate Scholarship.

\section{References}

[1] C.L. Ventola, The antibiotic resistance crisis: Part 1: Causes and threats, Pharm. Ther. 40 (2015) 277283.

[2] C.L. Ventola, The antibiotic resistance crisis: Part 2: Management strategies and new agents, Pharm. Ther. 40 (2015) 344-352.

[3] C.T. Walsh, T.A. Wencewicz, Prospects for new antibiotics: a molecule-centered perspective, J. Antibiot. 67 (2014) 7-22.

[4] K.A. Abrahams, G.S. Besra, Mycobacterial cell wall biosynthesis: a multifaceted antibiotic target, Parasitology 145 (2016) 116-133.

[5] D.W. Green, The bacterial cell wall as a source of antibacterial targets, Expert Opin. Ther. Targets 6 (2002) 1-20.

[6] T.D. Bugg, D. Braddick, C.G. Dowson, D.I. Roper, Bacterial cell wall assembly: still an attractive antibacterial target, Trends Biotechnol. 29 (2011) 167-173.

[7] T.D. Bugg, A.J. Lloyd, D.I. Roper, Phospho-MurNAc-pentapeptide translocase (MraY) as a target for antibacterial agents and antibacterial proteins, Infect. Disord. Drug Targets 6 (2006) 85-106.

[8] S. Rachakonda, L. Cartee, Challenges in antimicrobial drug discovery and the potential of nucleoside antibiotics, Curr. Med. Chem. 11 (2004) 775-793.

[9] S. Hirano, S. Ichikawa, A. Matsuda, Synthesis of Caprazamycin analogues and their structure-activity relationship for antibacterial activity, J. Org. Chem. 73 (2008) 569-577.

[10] K.-I. Kimura, T.D. Bugg, Recent advances in antimicrobial nucleoside antibiotics targeting cell wall biosynthesis, Nat. Prod. Rep. 20 (2003) 252-273. 

mureidomycins, Antimicrob. Agents Chemother. 36 (1992) 1024-1027.

[12] Y. Takahashi, M. Igarashi, T. Miyake, H. Soutome, K. Ishikawa, Y. Komatsuki, Y. Koyama, N. Nakagawa, S. Hattori, K. Inoue, Novel semisynthetic antibiotics from caprazamycins A-G: caprazene derivatives and their antibacterial activity, J. Antibiot. 66 (2013) 171-178.

[13] J.J. Salomon, P. Galeron, N. Schulte, P.R. Morow, D. Severynse-Stevens, H. Huwer, N. Daum, C.-M. Lehr, A.J. Hickey, C. Ehrhardt, Biopharmaceutical in vitro characterization of CPZEN-45, a drug candidate for inhalation therapy of tuberculosis, Ther. Deliv. 4 (2013) 915-923.

[14] M. Winn, R.J. Goss, K.-i. Kimura, T.D. Bugg, Antimicrobial nucleoside antibiotics targeting cell wall assembly: recent advances in structure-function studies and nucleoside biosynthesis, Nat. Prod. Rep. 27 (2010) 279-304.

[15] G. Niu, H. Tan, Nucleoside antibiotics: biosynthesis, regulation, and biotechnology, Trends Microbiol. 23 (2015) 110-119.

[16] T.D.H. Bugg, Nucleoside natural product antibiotics targeting microbial cell wall biosynthesis, in: J.F. Fisher, S. Mobashery, M.J. Miller (Eds.) Antibacterials: Volume II, Springer Int. Publishing, Cham, 2018, 125.

[17] S. Ichikawa, Function $\square$ oriented synthesis: how to design simplified analogues of antibacterial nucleoside natural products?, Chem. Rec. 16 (2016) 1106-1115.

[18] T.D. Bugg, M.T. Rodolis, A. Mihalyi, S. Jamshidi, Inhibition of phospho-MurNAc-pentapeptide translocase (MraY) by nucleoside natural product antibiotics, bacteriophage $\phi X 174$ lysis protein E, and cationic antibacterial peptides, Bioorg. Med. Chem. 24 (2016) 6340-6347.

[19] C. Dini, MraY inhibitors as novel antibacterial agents, Curr. Top. Med. Chem. 5 (2005) 1221-1236.

[20] S. Ichikawa, Fine synthetic nucleoside chemistry based on nucleoside natural products synthesis, Chem. Pharm. Bull. 56 (2008) 1059-1072.

[21] M. Serpi, V. Ferrari, F. Pertusati, Nucleoside derived antibiotics to fight microbial drug resistance: new utilities for an established class of drugs?, J. Med. Chem. 59 (2016) 10343-10382.

[22] I. Cheng-Sánchez, C. García-Ruiz, J.I. Trujillob, F. Sarabiaa, Synthesis and biological activity of the liposidomycins and caprazamycins, members of a novel class of diazepanone-containing nucleosides, Publisher: Societa Chimica Italiana. Targets in Heterocyclic Systems 19 (2015) 239-273.

[23] A. Bouhss, A.E. Trunkfield, T.D. Bugg, D. Mengin-Lecreulx, The biosynthesis of peptidoglycan lipidlinked intermediates, FEMS Microbiol. Rev. 32 (2007) 208-233.

[24] M. Kotnik, P.S. Anderluh, A. Prezelj, Development of novel inhibitors targeting intracellular steps of peptidoglycan biosynthesis, Curr. Pharm. Des. 13 (2007) 2283-2309.

[25] T. Schneider, H.-G. Sahl, An oldie but a goodie-cell wall biosynthesis as antibiotic target pathway, Int. J. Med. Microbiol. 300 (2010) 161-169.

[26] A. Gautam, R. Vyas, R. Tewari, Peptidoglycan biosynthesis machinery: a rich source of drug targets, Crit. Rev. Biotechnol. 31 (2011) 295-336.

[27] B.C. Chung, J. Zhao, R.A. Gillespie, D.-Y. Kwon, Z. Guan, J. Hong, P. Zhou, S.-Y. Lee, Crystal structure of MraY, an essential membrane enzyme for bacterial cell wall synthesis, Science 341 (2013) 10121016.

[28] S. Koppermann, C. Ducho, Natural products at work: structural insights into inhibition of the bacterial membrane protein MraY, Angew. Chem. Int. Ed. 55 (2016) 11722-11724.

[29] D.S. Boyle, W.D. Donachie, MraY is an essential gene for cell growth in Escherichia coli, J. Bacteriol. 180 (1998) 6429-6432.

[30] B. Al-Dabbagh, X. Henry, M.E. Ghachi, G. Auger, D. Blanot, C. Parquet, D. Mengin-Lecreulx, A. Bouhss, Active site mapping of MraY, a member of the polyprenyl-phosphate $N$-acetylhexosamine 1phosphate transferase superfamily, catalyzing the first membrane step of peptidoglycan biosynthesis, Biochemistry 47 (2008) 8919-8928.

[31] T. Tanino, B. Al-Dabbagh, D. Mengin-Lecreulx, A. Bouhss, H. Oyama, S. Ichikawa, A. Matsuda, Mechanistic analysis of muraymycin analogues: a guide to the design of MraY inhibitors, J. Med. Chem. 54 (2011) 8421-8439.

[32] C.T. Walsh, W. Zhang, Chemical logic and enzymatic machinery for biological assembly of peptidyl nucleoside antibiotics, ACS Chem. Biol. 6 (2011) 1000-1007.

[33] J. Hering, E. Dunevall, M. Ek, G. Brändén, Structural basis for selective inhibition of antibacterial target MraY, a membrane-bound enzyme involved in peptidoglycan synthesis, Drug Discov. Today 23 (2018) 1426-1435. 
[34] B.C. Chung, E.H. Mashalidis, T. Tanino, M. Kim, A.SMatsuda, J. Hong, S. Ichikawa, S.-Y. Lee, Structural insights into inhibition of lipid I production in bacterial cell wall synthesis, Nature 533 (2016) 557-560.

[35] J.K. Hakulinen, J. Hering, G. Brändén, H. Chen, A. Snijder, M. Ek, P. Johansson, MraY-antibiotic complex reveals details of tunicamycin mode of action, Nat. Chem. Biol. 13 (2017) 265-267.

[36] S. Barnard-Britson, X. Chi, K. Nonaka, A.P. Spork, N. Tibrewal, A. Goswami, P. Pahari, C. Ducho, J. Rohr, S.G. Van Lanen, Amalgamation of nucleosides and amino acids in antibiotic biosynthesis: discovery of an l-threonine:uridine-5'-aldehyde transaldolase, J. Am. Chem. Soc. 134 (2012) 18514-18517.

[37] M. Igarashi, N. Nakagawa, N. Doi, S. Hattori, H. Naganawa, M. Hamada, Caprazamycin B, a novel anti-tuberculosis antibiotic, from Streptomyces sp, J. Antibiot. 56 (2003) 580-583.

[38] M. Igarashi, Y. Takahashi, T. Shitara, H. Nakamura, H. Naganawa, T. Miyake, Y. Akamatsu, Caprazamycins, novel lipo-nucleoside antibiotics, from Streptomyces sp, J. Antibiot. 58 (2005) 327-337.

[39] P. Gopinath, T. Watanabe, M. Shibasaki, Studies on catalytic enantioselective total synthesis of caprazamycin B: construction of the western zone, J. Org. Chem. 77 (2012) 9260-9267.

[40] T. Takeuchi, M. Igarashi, H. Naganawa, M. Hamada, Antibiotic caprazamycins and process for producing the same, US 6780 616B1; EP1211259A1 (24 Aug 2004).

[41] S. Hirano, S. Ichikawa, A. Matsuda, Development of a highly $\beta$-selective ribosylation reaction without using neighboring group participation: total synthesis of (+)-caprazol, a core structure of caprazamycins, $\mathrm{J}$. Org. Chem. 72 (2007) 9936-9946.

[42] H. Nakamura, C. Tsukano, M. Yasui, S. Yokouchi, M. Igarashi, Y. Takemoto, Total synthesis of (-)caprazamycin A, Angew. Chem. Int. Ed. 54 (2015) 3136-3139.

[43] C. Dini, P. Collette, N. Drochon, J.C. Guillot, G. Lemoine, P. Mauvais, J. Aszodi, Synthesis of the nucleoside moiety of liposidomycins: elucidation of the pharmacophore of this family of MraY inhibitors, Bioorg. Med. Chem. Lett. 10 (2000) 1839-1843.

[44] C. Dini, N. Drochon, S. Feteanu, J.C. Guillot, C. Peixoto, J. Aszodi, Synthesis of analogues of the $O-\beta-$ D-ribofuranosyl nucleoside moiety of liposidomycins. Part 1: contribution of the amino group and the Uracil Moiety upon the inhibition of MraY, Bioorg. Med. Chem. Lett. 11 (2001) 529-531.

[45] C. Dini, N. Drochon, J.C. Guillot, P. Mauvais, P. Walter, J. Aszodi, Synthesis of analogues of the O- $\beta$ d-Ribofuranosyl nucleoside moiety of liposidomycins. Part 2: role of the hydroxyl groups upon the inhibition of MraY, Bioorg. Med. Chem. Lett. 11 (2001) 533-536.

[46] S. Hirano, S. Ichikawa, A. Matsuda, Structure-activity relationship of truncated analogs of caprazamycins as potential anti-tuberculosis agents, Bioorg. Med. Chem. 16 (2008) 5123-5133.

[47] S. Hirano, S. Ichikawa, A. Matsuda, Design and synthesis of diketopiperazine and acyclic analogs related to the caprazamycins and liposidomycins as potential antibacterial agents, Bioorg. Med. Chem. 16 (2008) 428-436.

[48] F. Sarabia, C. Vivar-García, C. García-Ruiz, L. Martín-Ortiz, A. Romero-Carrasco, Exploring the chemistry of epoxy amides for the synthesis of the 2"-epi-diazepanone core of liposidomycins and caprazamycins, J. Org. Chem. 77 (2012) 1328-1339.

[49] K.S. Kim, Y.H. Ahn, Synthesis of the diazepanone-nucleoside portion of liposidomycins by aldol reaction of the enolate of diazepanone with a nucleoside 5'-aldehyde, Tetrahedron: Asymmetry 9 (1998) 3601-3605.

[50] C. Gravier-Pelletier, M. Milla, Yves L. Merrer, J.-C. Depezay, Liposidomycins - synthetic studies towards the ribosyldiazepanone moiety, Eur. J. Org. Chem. 2001 (2001) 3089-3996.

[51] O. Monasson, M. Ginisty, G. Bertho, C. Gravier-Pelletier, Y. Le Merrer, Efficient synthesis of polyfunctionalised enantiopure diazepanone scaffolds, Tetrahedron Lett. 48 (2007) 8149-8152.

[52] O. Monasson, M. Ginisty, J. Mravljak, G. Bertho, C. Gravier-Pelletier, Y. Le Merrer, Synthetic studies towards diazepanone scaffolds, Tetrahedron: Asymmetry 20 (2009) 2320-2330.

[53] S. Knapp, S. Nandan, L. Resnick, Synthesis of the liposidomycin diazepanone, Tetrahedron Lett. 33 (1992) 5485-5486.

[54] S. Knapp, G.J. Morriello, G.A. Doss, Synthesis of the liposidomycin diazepanone nucleoside, Org. Lett. 4 (2002) 603-606.

[55] H. Miyaoka, J. Wada, E. Kawashima, Synthesis of the diazepanone-nucleoside core structure of liposidomycins and caprazamycins based on 7-exo cyclization of epoxyamine, Heterocycles 88 (2014) 719730.

[56] K. Ii, S. Ichikawa, B. Al-Dabbagh, A. Bouhss, A. Matsuda, Function-oriented synthesis of simplified caprazamycins: discovery of oxazolidine-containing uridine derivatives as antibacterial agents against drugresistant bacteria, J. Med. Chem. 53 (2010) 3793-3813. 

drug design, Acc. Chem. Res. 41 (2008) 40-49.

[58] M.J. Fer, S. Olatunji, A. Bouhss, S. Calvet-Vitale, C. Gravier-Pelletier, Toward analogues of MraY natural inhibitors: synthesis of 5'-triazole-substituted-aminoribosyl uridines through a $\mathrm{Cu}$-catalyzed azidealkyne cycloaddition, J. Org. Chem. 78 (2013) 10088-10105.

[59] M.J. Fer, A. Bouhss, M. Patrão, L. Le Corre, N. Pietrancosta, A. Amoroso, B. Joris, D. MenginLecreulx, S. Calvet-Vitale, C. Gravier-Pelletier, 5'-Methylene-triazole-substituted-aminoribosyl uridines as MraY inhibitors: synthesis, biological evaluation and molecular modeling, Org. Biomol. Chem. 13 (2015) 7193-7222.

[60] D. Wiegmann, S. Koppermann, M. Wirth, G. Niro, K. Leyerer, C. Ducho, Muraymycin nucleosidepeptide antibiotics: uridine-derived natural products as lead structures for the development of novel antibacterial agents, Beilstein J. Org. Chem. 12 (2016) 769-795.

[61] H. Zhao, Scaffold selection and scaffold hopping in lead generation: a medicinal chemistry perspective, Drug Discov. Today 12 (2007) 149-155.

[62] M. Yamaguchi, A. Matsuda, S. Ichikawa, Synthesis of isoxazolidine-containing uridine derivatives as caprazamycin analogues, Org. Biomol. Chem. 13 (2015) 1187-1197.

[63] T. Nakaya, A. Matsuda, S. Ichikawa, Design, synthesis and biological evaluation of 5'-C-piperidinyl-5'$O$-aminoribosyluridines as potential antibacterial agents, Org. Biomol. Chem. 13 (2015) 7720-7735.

[64] P.E. Brandish, M.K. Burnham, J.T. Lonsdale, R. Southgate, M. Inukai, T.D. Bugg, Slow binding inhibition of phospho- $N$-acetylmuramyl-pentapeptide-translocase (Escherichia coli) by mureidomycin A, J. Biol. Chem. 271 (1996) 7609-7614.

[65] T. Tanino, M. Yamaguchi, A. Matsuda, S. Ichikawa, Function-oriented synthesis of liponucleoside antibiotics, Eur. J. Org. Chem. 2014 (2014) 1836-1840.

[66] Y. Ishizaki, C. Hayashi, K. Inoue, M. Igarashi, Y. Takahashi, V. Pujari, D.C. Crick, P.J. Brennan, A. Nomoto, Inhibition of the first step in synthesis of the mycobacterial cell wall core, catalyzed by the GlcNAc-1-phosphate transferase WecA, by the novel caprazamycin derivative CPZEN-45, J. Biol. Chem. 288 (2013) 30309-30319.

[67] D.T. Hoagland, J. Liu, R.B. Lee, R.E. Lee, New agents for the treatment of drug-resistant Mycobacterium tuberculosis, Adv. Drug Deliv. Rev. 102 (2016) 55-72.

[68] S. Ichikawa, M. Yamaguchi, L.S. Hsuan, Y. Kato, A. Matsuda, Carbacaprazamycins: chemically stable analogues of the caprazamycin nucleoside antibiotics, ACS Infect. Dis. 1 (2015) 151-156.

[69] B.D. Mallavarapu, M. Abdullah, S. Saxena, L. Guruprasad, Inhibitor binding studies of Mycobacterium tuberculosis MraY (Rv21 56c): insights from molecular modeling, docking, and simulation studies, J. Biomol. Struct. Dyn. 36 (2018) 1-13.

[70] S. Siricilla, K. Mitachi, B. Wan, S.G. Franzblau, M. Kurosu, Discovery of a capuramycin analog that kills nonreplicating Mycobacterium tuberculosis and its synergistic effects with translocase I inhibitors, J. Antibiot. 68 (2014) 271-278. 
- Nucleoside antibiotics caprazamycins are the most promising lead structures acting on a novel antibacterial target MraY.

- A systematic review on the structure-activity relationships (SAR) of caprazamycins was carried out.

- The SAR study revealed the essential pharmacophores present in caprazamycins nucleoside antibiotics.

- Antibacterial spectrum of the natural, semi-synthetic and synthetic analogues of caprazamycins are described. 


\section{Accepted Manuscript}

Caprazamycins: Promising lead structures acting on a novel antibacterial target MraY

Bhautikkumar Patel, Philip Ryan, Vivek Makwana, Matthew Zunk, Santosh Rudrawar, Gary Grant

PII:

S0223-5234(19)30091-1

DOI:

https://doi.org/10.1016/j.ejmech.2019.01.071

Reference: EJMECH 11078

To appear in: European Journal of Medicinal Chemistry

Received Date: 10 December 2018

Revised Date: 24 January 2019

Accepted Date: 28 January 2019

Please cite this article as: B. Patel, P. Ryan, V. Makwana, M. Zunk, S. Rudrawar, G. Grant, Caprazamycins: Promising lead structures acting on a novel antibacterial target MraY, European Journal of Medicinal Chemistry (2019), doi: https://doi.org/10.1016/j.ejmech.2019.01.071.

This is a PDF file of an unedited manuscript that has been accepted for publication. As a service to our customers we are providing this early version of the manuscript. The manuscript will undergo copyediting, typesetting, and review of the resulting proof before it is published in its final form. Please note that during the production process errors may be discovered which could affect the content, and all legal disclaimers that apply to the journal pertain. 